\title{
Invasive occurrence and abundance changes of Armadillidium vulgare (Latreille, 1804) in Hungarian roadside verges
}

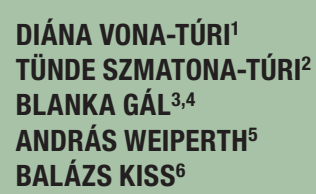

${ }^{3}$ MTA Centre for Ecological Research, Balaton Limnological Institute, Klebelsberg Kuno steet 3. Tihany 8237, Hungary

${ }^{4}$ Doctoral School of Environmental Sciences, Eötvös Loránd University, H-1117 Budapest, 1/C Pázmány Péter promenade, Hungary, E-mail: galblankaa@gmail.com, ORCID: 0000-0001-8513-3010

${ }^{5}$ Centre for Ecological Research, Hungarian Academy of Sciences, Danube Research Institute, H-1113 Budapest, 29. Karolina road, Hungary, E-mail: weiperth.andras@okologia.mta.hu, ORCID: 0000-0001-7824-68853

${ }^{6}$ Center of Agricutural Research, Hungarian Academy of Sciences. Plant Protection Institute H-1022 Budapest, 15. Herman Ottó road, Hungary, E-mail: kiss.balazs@agrar.mta.hu, ORCID:0000-0003-2511-9094

\section{Correspondence:}

Diána Vona-Túri

E-mail: turidiana79@gmail.com

Key words: vegetation; disturbance, road-edge proximity; leaf-litter; highway operation time; mowing

Received September 17, 2017.

Revised July 02, 2018.

Accepted April 30, 2019.

\begin{abstract}
Background and purpose: The impact of invasive species in ecosystems is an important problem worldwide and the spreading of invader species are affected exceedingly by linear infrastructure. Primarily the aim of our investigation was to studied how the invasion of the species impacts the isopod diversity of roadside verges. Secondly, we determined what attributes of linear infrastructure affect on mass occurrence by the species.
\end{abstract}

Materials and methods: Double-glass pitfall traps were established 30 localities along highways and 4 localities along main roads in Hungary between 2011 and 2016. To studied what attributes of roads affect the abundance of $\mathrm{A}$. vulgare we considered seasons, adjacent areas, road edge proximity, leaflitter depth, the age of highway, vegetation type and mowing.

Results: We collected a total of 18 isopod species. The A. vulgare was the most abundant and frequently encountered species in both road types, which represented $89 \%$ of the total isopod catches. The high abundance of the species negatively correlated with isopod diversity. The invasive nature of this species is promoted by summer season, the proximity of arable fields, intermediate distance from the road, leaflitter at a depth of $0 \mathrm{~cm}$ and the young age of highways. On mainroad verges the highest abundance was in the non-mown sections of the arid grassland sites.

Conclusions: Our results suggest that this species is likely to adversely impact ecosystem function of roadside verges in Hungary. Different land use, water supply, surrounding landscapes, habitat structure, vegetation, biogeographical context and human activities along road verges influence the invasiveness of $\mathrm{A}$. vulgare.

\section{INTRODUCTION}

$\mathbf{R}$ oadside verges function as prime habitats for several native, exotic Rand invasive animal and plant species $(1,2,3,4)$. Roads provide not only refuges for protected and endangered species in agriculturallydominated landscapes but also function as invasion pathways for arthropods $(5,6,7,8)$. However, roads also exert significant negative effects on communities, wildlife populations and ecosystems of surrounding habitats (9). The presence of roads and traffic may alter the chemical environment, modify animal behaviourand provide dispersal routes for species (1). Linear infrastructure, vehicles and roadside verges may be important elements in determining the spatial spread of an organism's distribution $(6,10)$. In heavily disturbed and modified habitats such as highways, invasive species have a chance to adapt and spread along 
roadsides by the green corridor effect (11). The distribution of other species is reduced or becomes isolated to facilitate the expeditious spread of invasive species (12). However, not all new species can adapt and spread in the new area after entering and become invasive, as the „tens rules" by Williamson \& Fitter (13) illustrates well. In the new habitats, $10 \%$ of imported species can escape to the wild, $10 \%$ of occasionally colonizing species become naturalized, and only $10 \%$ of naturalized species become invasive. Over recent decades the spread of invasive species is related to climate change and the ever-increasing development of international commerce (14). The appearance of a new invasive species into an ecosystem often does not result in an immediate impact, furthermore, in many cases, it is difficult to estimate which species are essential to ecosystem functioning and which are redundant (15). The presence of invasive species in ecosystems is a remarkable problem worldwide because they have an impact on the structure and function of ecosystems, and biodiversity and the loss of habitats, and invader species can cause serious environmental, economic or social damage (16). Clavero \& García-Berthou (17) showed that overgrowth of invasive species contributed to $54 \%$ of extinction of animal species.

Firstly, the main objectives of this study were to investigate the invasive occurrence of $A$. vulgare along Hungarian highways, and we studied how the invasion of the species impacts the isopod diversity of highway verges.

1) We hypothesised that $A$. vulgare has a negative effect on the diversity of the isopod communities because of the species invasiveness. Secondly, we explored what attributes of roads (seasons, adjacent areas, road edge proximity, leaf-litter depth, highway age, vegetation and mowing) affect the abundance of $A$. vulgare.
2) We compared the abundance of $A$. vulgare based on seasons in highway verges. We assumed that the maximum number of individuals will peak abundance in autumn because of its semelpar reproduction (18).

3) We studied the effect of adjacent areas of highway verges on $A$. vulgare abundance. Our hypothesis was that this species prefers disturbed open habitats compared to other isopod species which prefer wet forested habitats, because of the species is an indicator of anthropogenic impacts.

4) We analysed the effects of road edge proximity on highways and we expected that the highest abundance of $A$. vulgare would occur at an intermediate distance from the road, because of the intermediate disturbance hypothesis.

5) We compared the abundance of $A$. vulgare in highway sampling sites based on leaf-litter depth between $0-5$ $\mathrm{cm}$ intervals. We hypothesised that the species abundance would increase with leaf-litter depth, because of the species contribution to decomposition processes.

6) We assessed differences between sampling sites based on highway age. We hypothesised that there would be a decrease in the abundance of the species from the oldest sites to the youngest sites, because of the invasive nature of this species.

7) In main roads we examined the effect of the main Hungarian vegetation types and we expected the highest abundance of $A$. vulgare in open habitats, such as grasslands.

8) Finally, we analysed the effect of mowing on the abundance of $A$. vulgare on main roads. Our hypothesis was that the mowing would negatively affect the number of individuals.

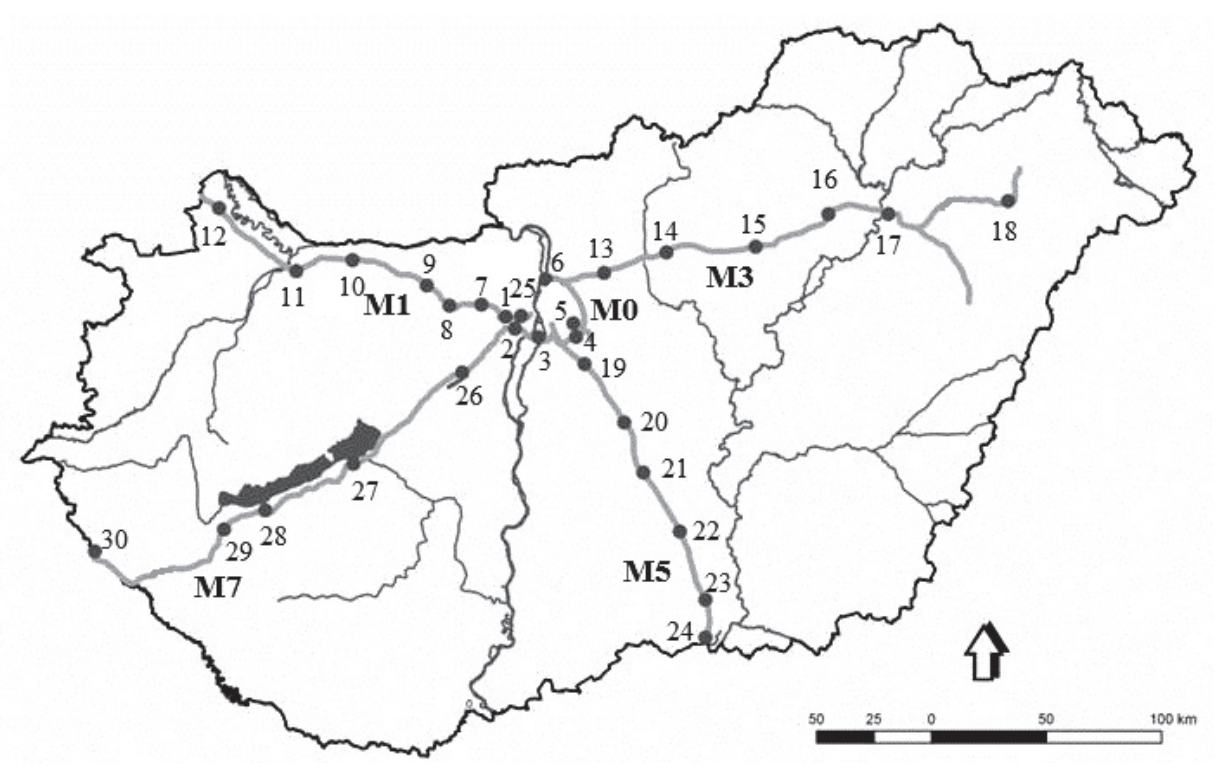

Figure 1. Map of highways and the sampling sites. The code of sampling sites can be found in Table 1 
Table 1. Characterization of sampling sites along highway

\begin{tabular}{|c|c|c|c|c|c|c|}
\hline Highway & Code & Sampling sites & Adjacent area & $\begin{array}{l}\text { Leaf litter cover } \\
\text { (\%) }\end{array}$ & $\begin{array}{l}\text { Leaf litter } \\
\text { depth }(\mathrm{cm})\end{array}$ & Soil \\
\hline \multirow{6}{*}{ M0 } & 1 & $0 \mathrm{~km}$ sos & urban & 15 & 3 & construction debris \\
\hline & 2 & Anna-hegy & orchard & 15 & 1 & gravelly \\
\hline & 3 & Csepel & urban & 40 & 2 & sand \\
\hline & 4 & Alacska & grassland & 30 & 1 & sand \\
\hline & 5 & Ferihegy & grassland & 10 & 4 & $\begin{array}{l}\text { gravelly, } \\
\text { clastic }\end{array}$ \\
\hline & 6 & Dunakeszi & forest & 20 & 3 & clastic \\
\hline \multirow{6}{*}{ M1 } & 7 & Zsámbék & arable land & 95 & 1 & light loess \\
\hline & 8 & Óbarok & forest & 98 & 0.5 & light loess \\
\hline & 9 & Turul & orchard & 98 & 6 & light loess \\
\hline & 10 & Bábolna & arable land & 75 & 2 & dark humus \\
\hline & 11 & Arrabona & arable land & 100 & 5 & humic sand \\
\hline & 12 & Moson & arable land & 40 & 0.5 & dark gravelly \\
\hline \multirow{6}{*}{ M3 } & 13 & Kisbag & forest & 10 & 1 & sand \\
\hline & 14 & Ecséd & orchard & 10 & 1 & black loose \\
\hline & 15 & Rekettyés & arable land & 0 & 0 & black loam \\
\hline & 16 & Gelej & arable land & 5 & 1 & black loam \\
\hline & 17 & Polgár & arable land & 5 & 1 & sand \\
\hline & 18 & Nyíregyháza & arable land & 10 & 4 & loessal \\
\hline \multirow{6}{*}{ M5 } & 19 & Inárcs & sand grass & 20 & 0.5 & sand \\
\hline & 20 & Örkény & forest & 20 & 0.2 & light sandy \\
\hline & 21 & Kecskemét & arable land & 80 & 0.2 & dark humus \\
\hline & 22 & Petőfiszállás & arable land & 100 & 0.2 & dark humus \\
\hline & 23 & Szatymaz & grassland & 100 & 1 & dark humus \\
\hline & 24 & Röszke & sand grass & 100 & 5 & sand \\
\hline \multirow{6}{*}{ M7 } & 25 & Budaörs & urban & 100 & 0.2 & darl loess \\
\hline & 26 & Velence & orchard & 100 & 5 & light loess \\
\hline & 27 & Törek & arable land, forest & 98 & 1 & brown, loessal \\
\hline & 28 & Táska & grassland & 50 & 0.2 & light sandy \\
\hline & 29 & Szegerdő & arable land & 2 & 0.2 & light gravelly \\
\hline & 30 & Letenye & forest & 98 & 0 & gravelly, loam \\
\hline
\end{tabular}

\section{MATERIAL AND METHODS}

\section{Study sites and sampling procedure}

\section{Highways}

Data collection was done along 5 Hungarian highways (M0, M1, M3, M5, M7) (Figure 1). Highway M0 is considered to be the main road but it is managed as a highway in Hungary, because the traffic intensity on the main road is the same as that of highways. Thirty sampling points were selected in the highway verges that were located among neighbouring habitats with different type of vegetation and various level of disturbance. Along each highway we selected 6-6 sampling points (Table 1) where a total of 180 double-glass pitfall traps made of $3 \mathrm{dl}$ plastic cups filled with a $65 \%$ aqueous solution of ethylene glycol were established. Sampling sites were selected next to the lay-bys along highway where isopods were sampled using 6-6 pitfall traps at each site and the distance between traps was $5 \mathrm{~m}$. The traps were deployed three times (spring, summer, autumn) over a three-week period each year. On highways, we studied the effects of seasons, ad- 
Table 2. Sampling sites along highways used to examine the effect of adjacent areas and road edge proximity

\begin{tabular}{|c|c|c|c|c|}
\hline & $\begin{array}{l}\text { Types of } \\
\text { acent areas }\end{array}$ & Highway & $\begin{array}{l}\text { Sampling } \\
\text { site }\end{array}$ & $\begin{array}{c}\text { Distance from } \\
\text { the road }(-)\end{array}$ \\
\hline & & M5 & Röszke & $20 \mathrm{~m}$ \\
\hline & Grasslands & M0 & Ferihegy & $40 \mathrm{~m}$ \\
\hline$\frac{\pi}{\sigma} \bar{J}$ & & M7 & Táska & $90 \mathrm{~m}$ \\
\hline$\underset{\tilde{J}}{\bar{E}} \cdot \frac{T}{\varepsilon}$ & & M5 & Örkény & $20 \mathrm{~m}$ \\
\hline & Forest & M3 & Kisbag & $40 \mathrm{~m}$ \\
\hline & & M1 & Óbarok & $90 \mathrm{~m}$ \\
\hline & & M0 & $0 \mathrm{~km}$ & $20 \mathrm{~m}$ \\
\hline & Urban & M7 & Budaörs & $40 \mathrm{~m}$ \\
\hline & & M0 & Csepel & $90 \mathrm{~m}$ \\
\hline T્ષ & & M3 & Ecséd & $20 \mathrm{~m}$ \\
\hline $\bar{\Xi}$ & Orchard & M1 & Turul & $40 \mathrm{~m}$ \\
\hline$\ddot{\theta}$ & & M7 & Velence & $90 \mathrm{~m}$ \\
\hline & & M7 & Szegerdő & $20 \mathrm{~m}$ \\
\hline & Arable land & M3 & Polgár & $40 \mathrm{~m}$ \\
\hline & & M5 & Kecskemét & $90 \mathrm{~m}$ \\
\hline
\end{tabular}

Table 3. Sampling sites along highways used to examine the effect of leaf-litter depth

\begin{tabular}{|ccc|}
\hline Highways & Sampling sites & Leaf litter depth $(\mathrm{cm})$ \\
\hline M7 & Letenye & 0 \\
M3 & Rekettyés & \\
M0 & Alacska & 1 \\
M3 & Gelej & \\
M0 & Csepel & 2 \\
M1 & Bábolna & \\
M0 & Dunakeszi & 3 \\
M0 & 0 km & \\
M0 & Ferihegy & 4 \\
M3 & Nyíregyháza & \\
M5 & Röszke & 5 \\
M1 & Arrabona & \\
\hline
\end{tabular}

jacent areas, road edge proximity, leaf litter depth and the age of highways on the abundance of $A$. vulgare. Selection of sampling sites and coordination of sampling methods were occurred by the Center of Agricultural Research, Hungarian Academy of Sciences, Plant Protection Institute. When we analysed the effect of different factors on the abundance of $A$. vulgare, we did not consider the data of all 30 sampling sites except for annual and seasonal examination. To examine the effect of adjacent areas and
Table 4. Sampling sites along highways used to examine the effect of age of highway

\begin{tabular}{|ccc|}
\hline Sampling sites & Highways & Year of establishment \\
\hline Arrabona & M1 & 1977 \\
Bábolna & M1 & \\
Turul & M1 & 1982 \\
Óbarok & M1 & \\
Kecskemét & M5 & 1989 \\
Örkény & M5 & \\
Polgár & M3 & 2002 \\
Gelej & M3 & \\
Ferihegy & M0 & 2008 \\
Szegerdo” & M7 & \\
\hline
\end{tabular}

road edge proximity, we selected 15 sampling sites (see Table 2). To assess the effect of leaf litter depth, we considered 12 sampling sites (see Table 3). To examine the effect of age of highways, we selected 10 sampling sites (see Table 4).

\section{Main roads}

Along Hungarian main roads data was collected at four sampling sites representing the main types of verge habitats between 2014-2016 (Figure 2). Verge types were categorised based on the vegetation type of neighboring habitats. Sampling area Pilisjászfalu (Road No. 10) consisted of arid grassland with some small bushes. Mány (Road No. 1) was situated in the lowlands and hilly landscapes of Hungary, and was bordered by 2 roads running through agricultural land. Herceghalom (Road No.1) was situated next to a forest. Agárd (Road No. 7) crosses a wetland area in the west section of Lake Velence. All localities included three sections representing (1) no maintenance (non mown) (2) normal maintenance (mown once a year) and (3) enhanced maintenance (mown twice or three times a year). The distance between 2 sections was $100 \mathrm{~m}$. In each section five pitfall traps were established 5 meters apart, and they were located 1,5 meters from the roads. Double glass pitfall traps filled with ethylene glycol were used which were left in the fields for three weeks and three times a year in different seasons (spring, summer and autumn). We collected samples after first mowing in between May and June. After the second mowing the field experiment was repeated twice in $\mathrm{Au}$ gust and September. Trapped specimens were preserved in 75 percent alcohol. Sampling methods made it possible to study the effects of vegetation type and mowing on abundance of $A$. vulgare. Selection of sampling sites and coordination of sampling methods were occured by the Centre for Ecological Research, Hungarian Academy of Sciences, Danube Research Institute. 


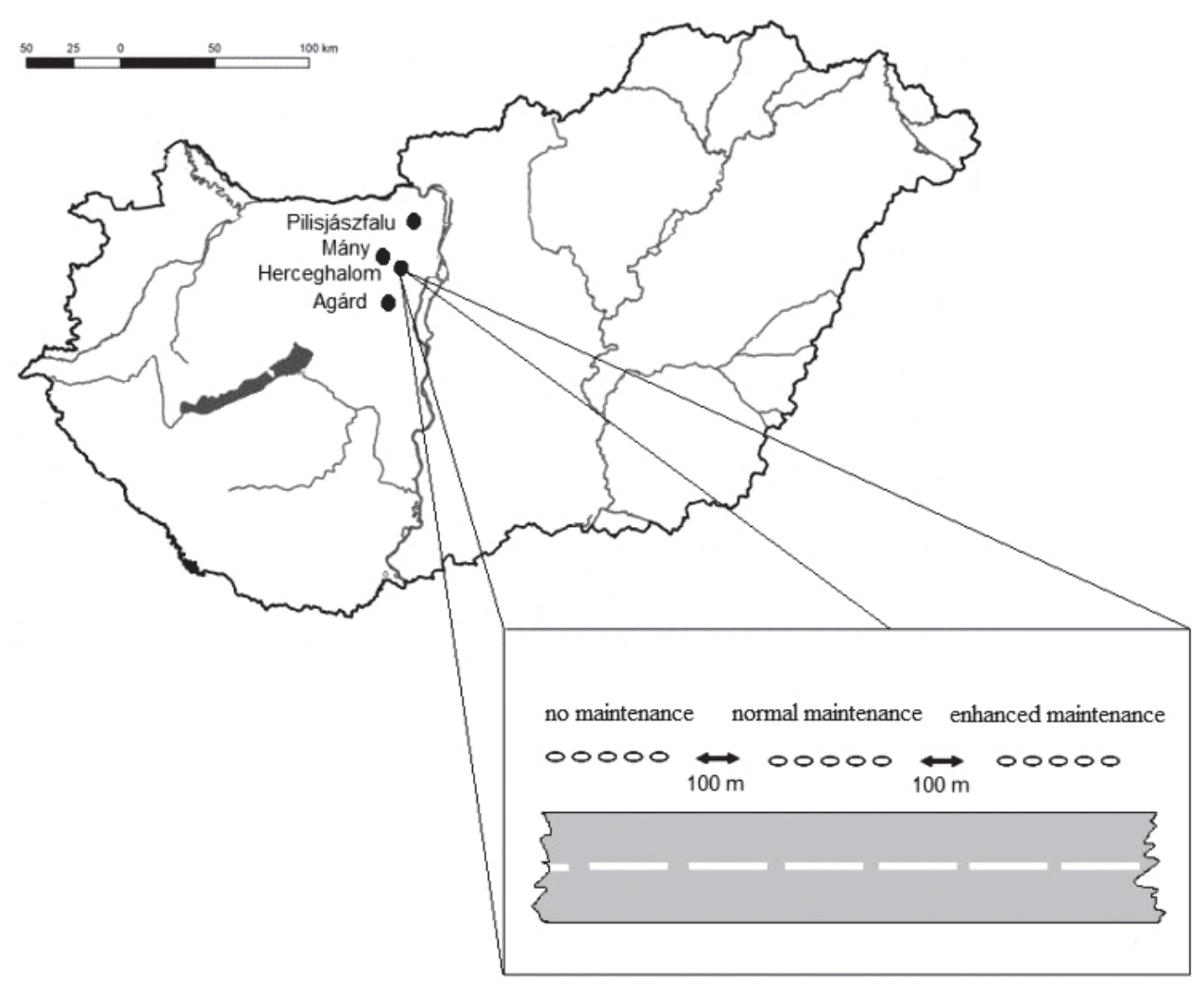

Figure 2. Sampling sites and treatment along main roads

\section{Data analysis}

We used the PAST Paleontological Statistic suite for data analysis (19). Besides a number of individuals, we computed Shannon-Wiener diversity in order to analyse the invasive patterns of $A$. vulgare. The Shannon-Wiener index is more sensitive to the frequency of rare species (20, $21,22)$. Species with the highest abundance have the greatest influence on the Simpson's index $(20,21,22)$. The characterization of the $A$. vulgare population was based on relative abundance (Ar) and frequency $(\mathrm{F})$. The years were the replications, except for the case of the annual population dynamics, when sampling dates were the replications. One-Way ANOVA was applied to assess the differences between the number of individuals of A. vulgare in relation to years, seasons, adjacent areas, road edge proximity, leaf-litter depth and highway age. We used the keys of Hopkin (23), Schmidt (24), and Farkas \& Vilisics (25) for identification of isopod specimens. Species' names were applied according to Schmalfuss (26).

\section{RESULT}

\section{$\gamma$-diversity}

Along main roads, we collected 6 isopod species and on highway verges 18 species. During our study A. vulgare was the most abundant isopod species (highways: Ar
$=89 \%$ of a total number of individuals collected, main roads: $\mathrm{Ar}=89 \%$ ) and frequent species (highways: $\mathrm{F}=$ $94 \%$, main roads: $\mathrm{F}=100 \%$ ). A total of 52361 specimens of $A$. vulgare were collected along roads, composed of 45626 individuals on highway verges and 6735 individuals on main road verges.

\section{Highways}

We examined the annual population dynamics along highways and we found no significant differences $(\mathrm{p}=0.416)$ in abundance of $A$. vulgare. The number of $A$. vulgare, the relative abundance and the frequency increased with years (Figure 3). Simultaneously, the values of Shannon-Wiener diversity of isopods along highways decreased with years, beacause it was significantly lower $(\mathrm{p}=0.049)$ in 2013 compared to 2011 (Figure 4).

Significant differences were no found between number of $A$. vulgare ( $\mathrm{p}=0.287)$ in relation to season. The number of the species was the highest in summer and the lowest was in autumn. The highest relative abundance and frequency of the species also were in summer, while the lowest was in autumn (Figure 5).

We found statistically significant differences in number of $A$. vulgare $(\mathrm{p}=0.013)$ in relation to adjacent areas of highways. Abundance of $A$. vulgare was significantly higher next to arable lands compared to verges next to 
forests, urban areas and orchards. The relative abundance of the species was lowest next to urban areas than the other verges, while the frequency of the species was 100\% in each verges (Figure 6).
Significant differences were found between number of the species $(\mathrm{p}=0.045)$ in relation to road edge proximity. The number of $A$. vulgare was significantly higher at 40 $\mathrm{m}$ from the road than at $20 \mathrm{~m}$ from the road. The relative
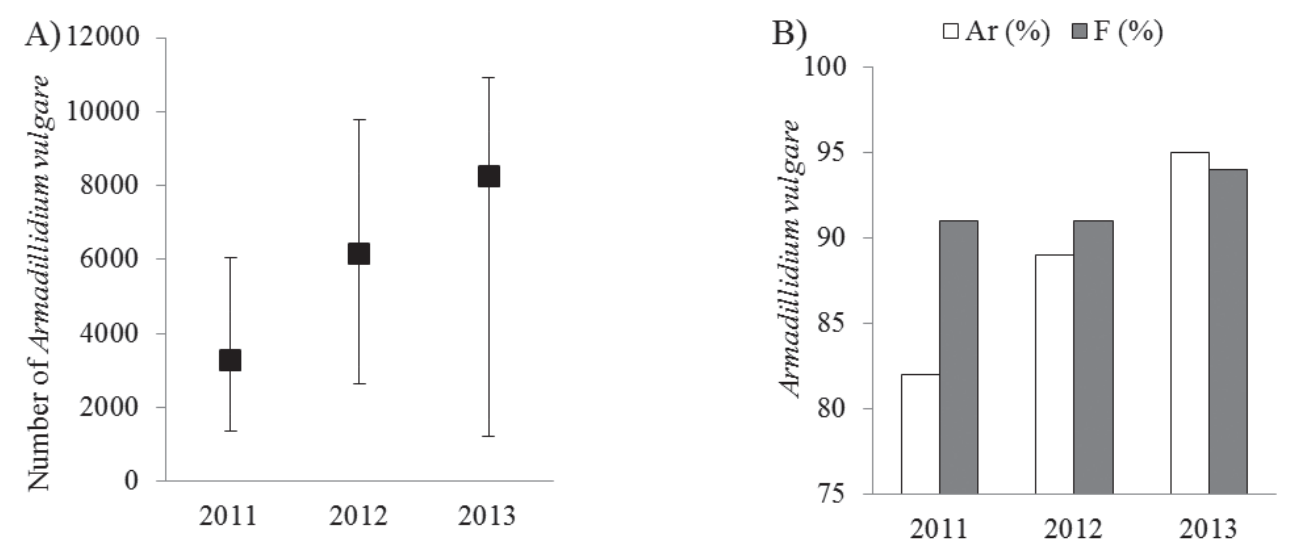

Figure 3. Annual population dynamics of abundance (A), and relative abundance and frequency (B) of A. vulgare (average \pm S. E.).
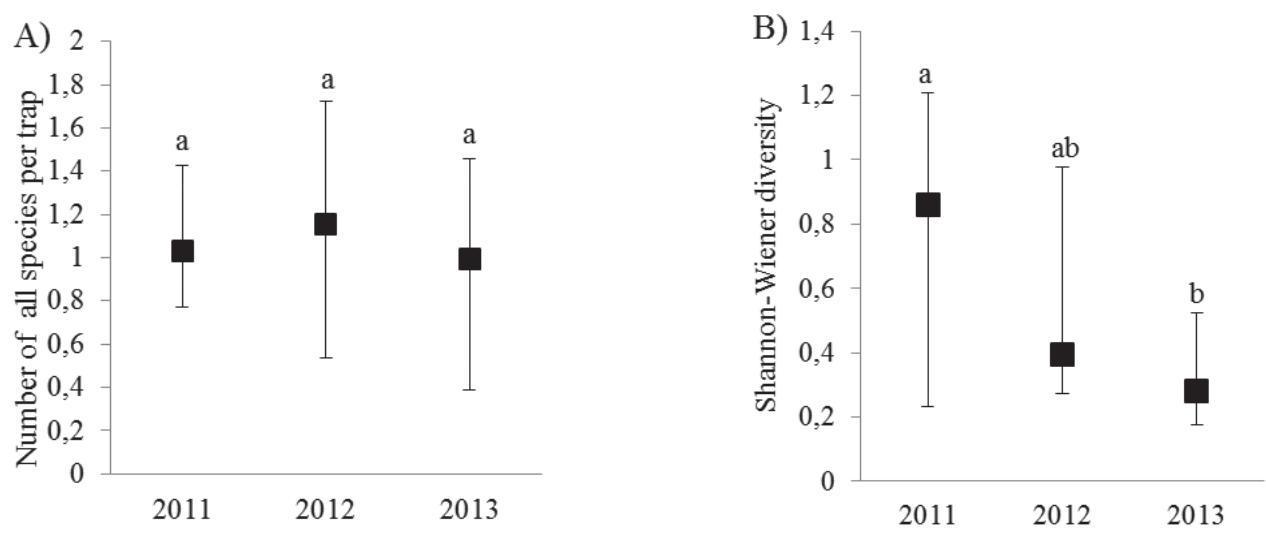

Figure 4. Annual population dynamics of species richness (A) and Shannon-Wiener diversity (B) of isopod assemblages in highway verges (average \pm S.E.). Different letters indicate significant $(p<0.05)$ differences (one-way ANOVA)
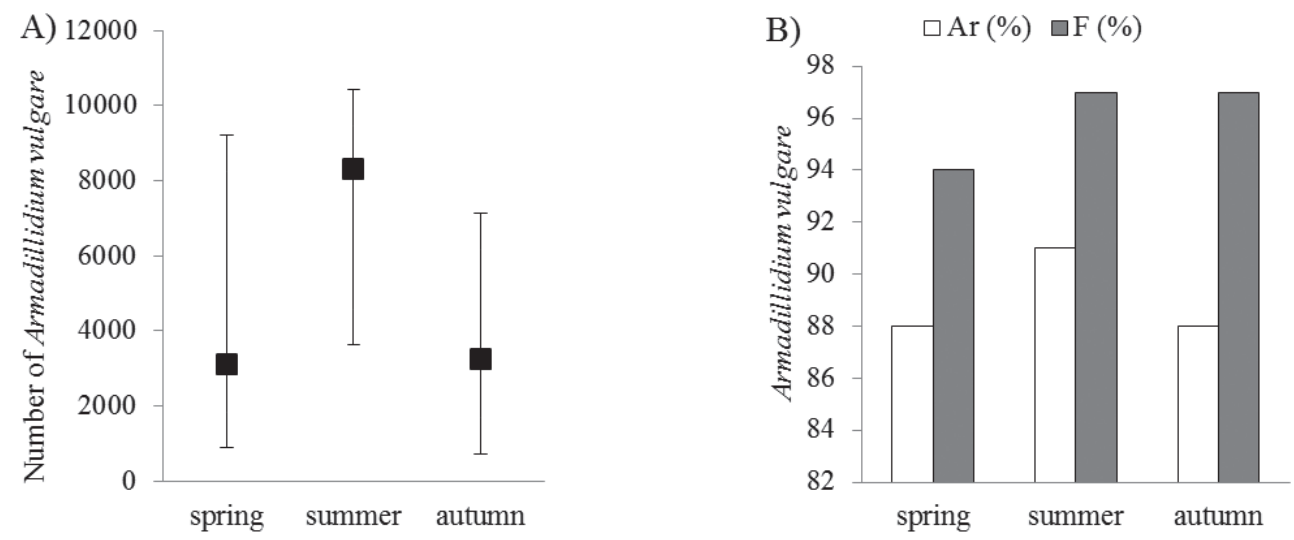

Figure 5. Abundance (A) and relative abundance and frequency (B) of A. vulgare in highway verges in relation to season (average \pm S.E.). 

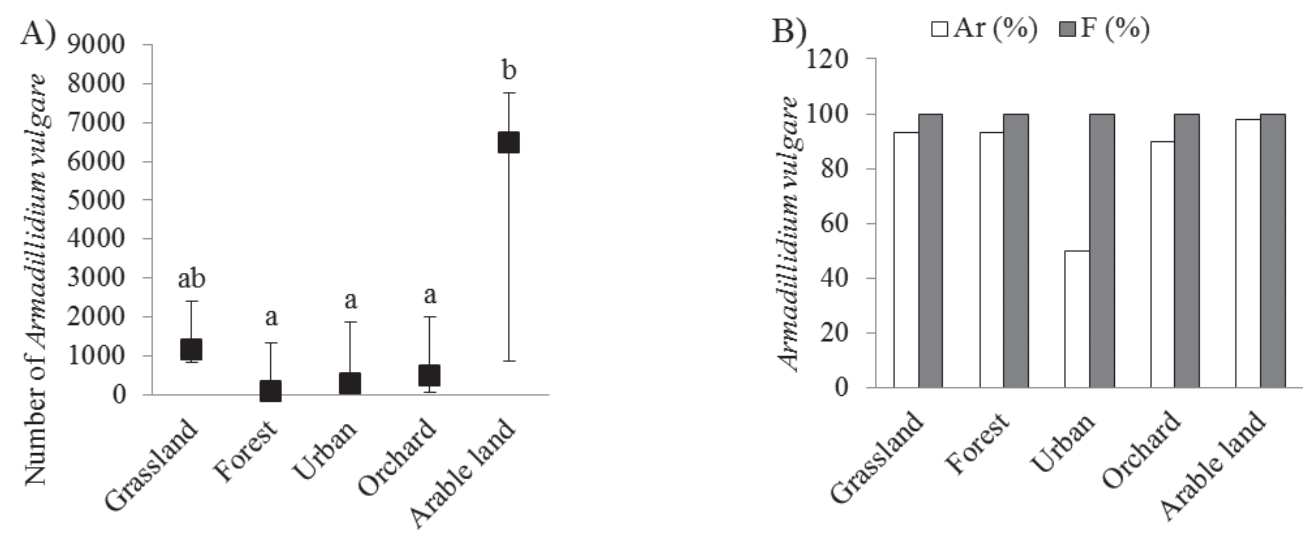

Figure 6. Abundance $(A)$ and relative abundance and frequency $(B)$ of A. vulgare in highway verges in relation to adjacent areas (average \pm S.E.). Different letters indicate significant $(p<0.05)$ differences (one-way ANOVA)
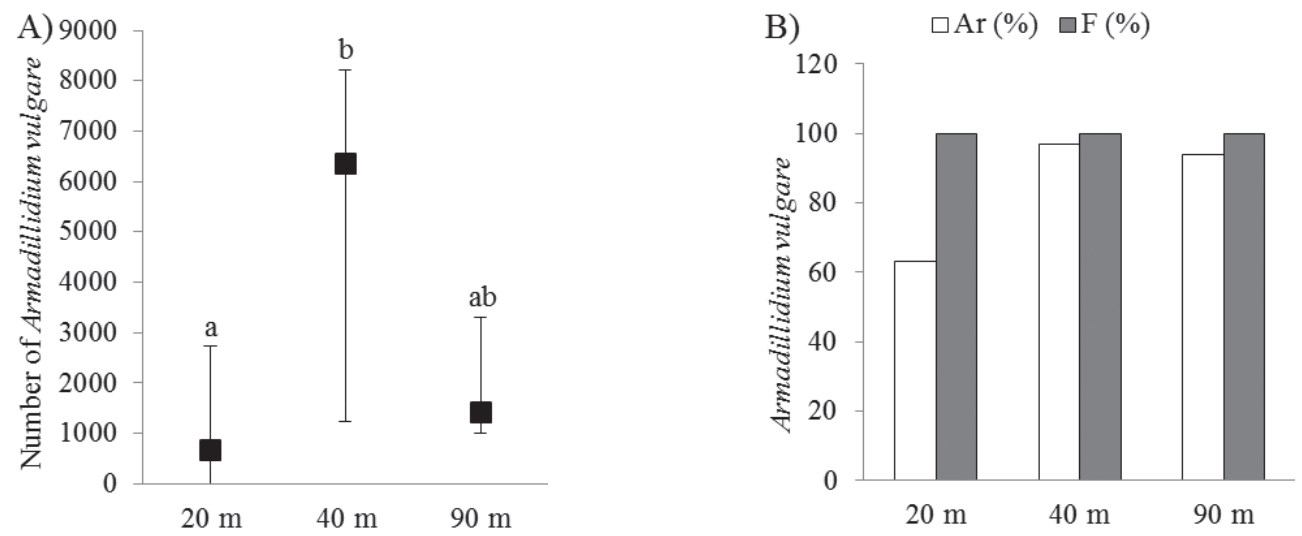

Figure 7. Abundance $(N)$ and relative abundance and frequency (B) of A. vulgare in highway verges located at different distances $(20 \mathrm{~m}$, $40 \mathrm{~m}$ and $90 \mathrm{~m}$ ) from roads (average \pm S.E.). Different letters indicate significant $(p<0.05)$ differences (one-way ANOVA)
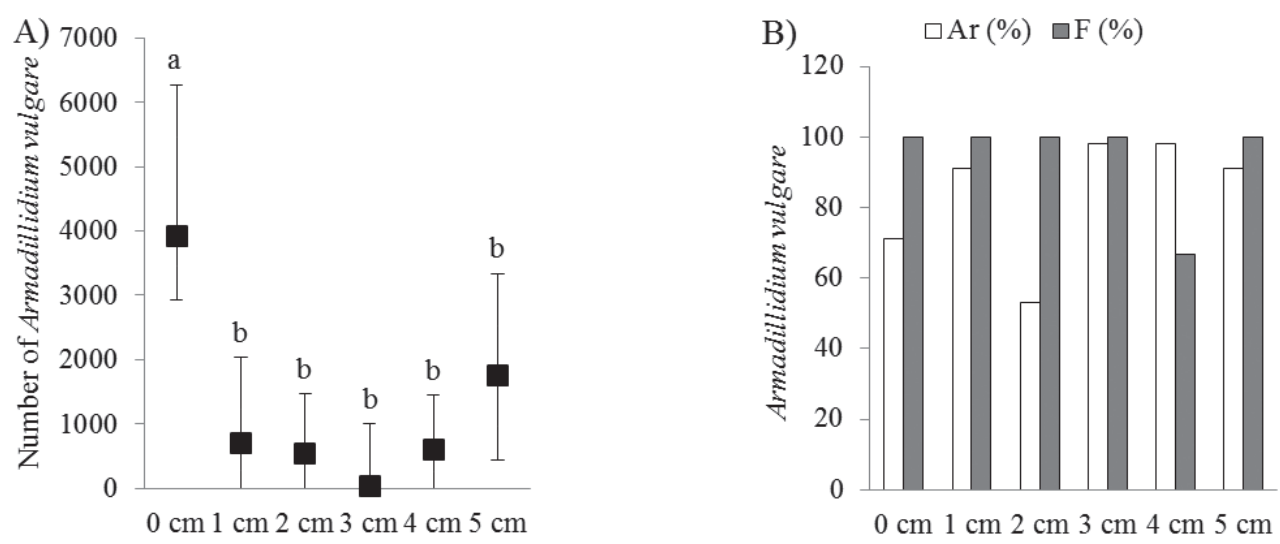

Figure 8. Abundance $(N)$ and relative abundance and frequency $(B)$ of A. vulgare in highway verges relative to leaf-litter depth in the verges that were examined (average \pm S.E.). Different letters indicate significant $(p<0.05)$ differences (one-way ANOVA)

abundance of $A$. vulgare was lowest at $20 \mathrm{~m}$ from the road and the frequency of the species was equal in each distance from the road (Figure 7).
There were significant differences $(\mathrm{p}=0.00016)$ in abundance of $A$. vulgare in relation to leaf-litter depth. The number of $A$. vulgare was significantly highest in sam- 

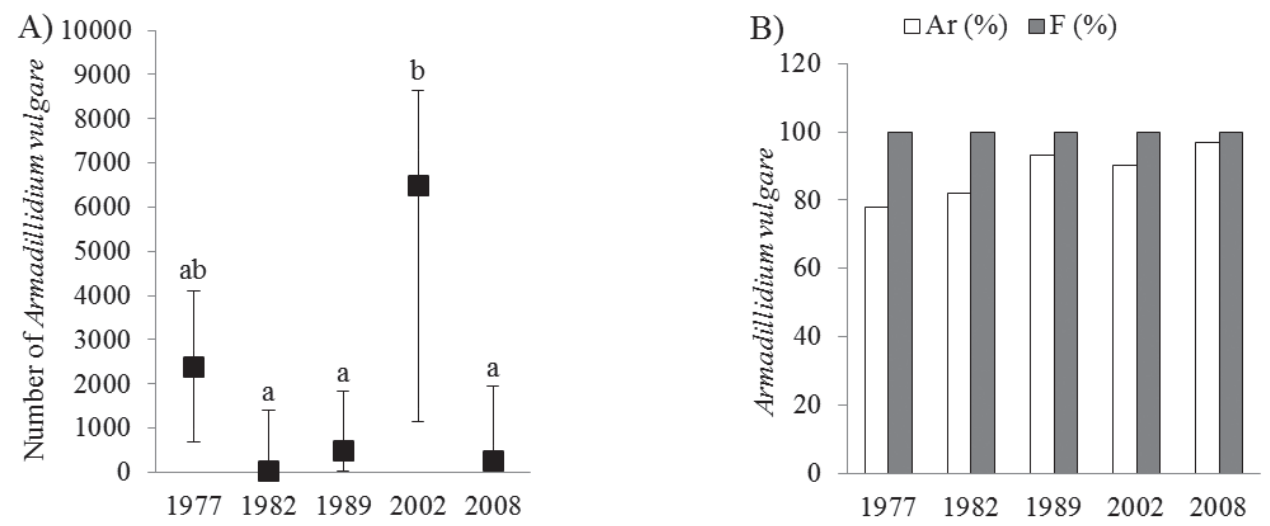

Figure 9. Abundance $(N)$ and relative abundance and frequency $(B)$ of A. vulgare in highway verges relative to the year when highway have been finished (average \pm S.E.). Different letters indicate significant $(p<0.05)$ differences (one-way ANOVA)
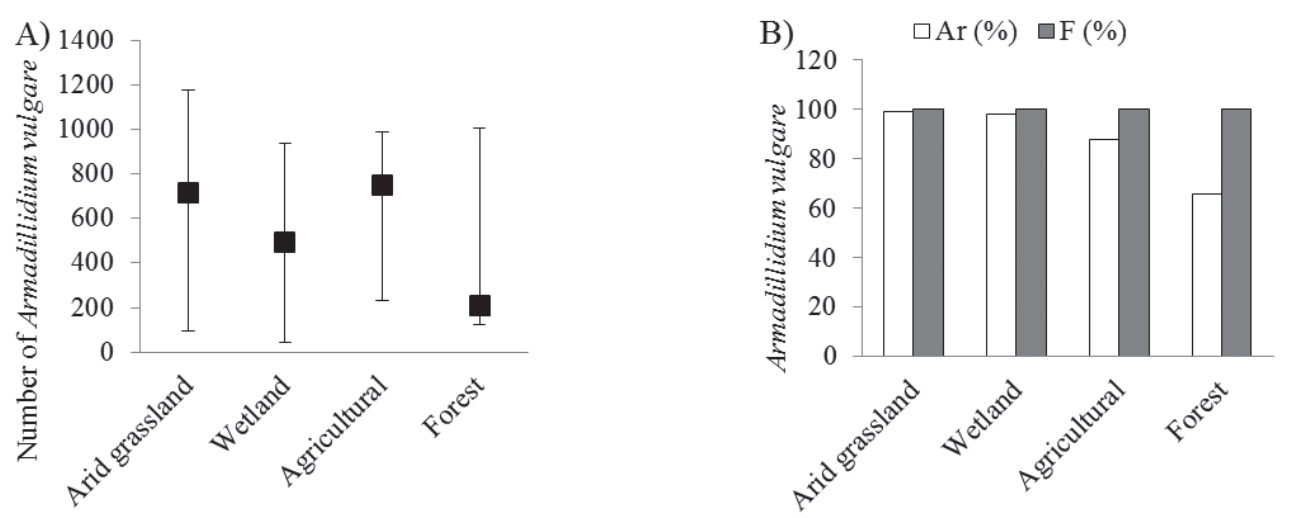

Figure 10. Abundance $(N)$ and relative abundance and frequency $(B)$ of A. vulgare in mainroad verges relative to the vegetation type (average \pm S.E.).
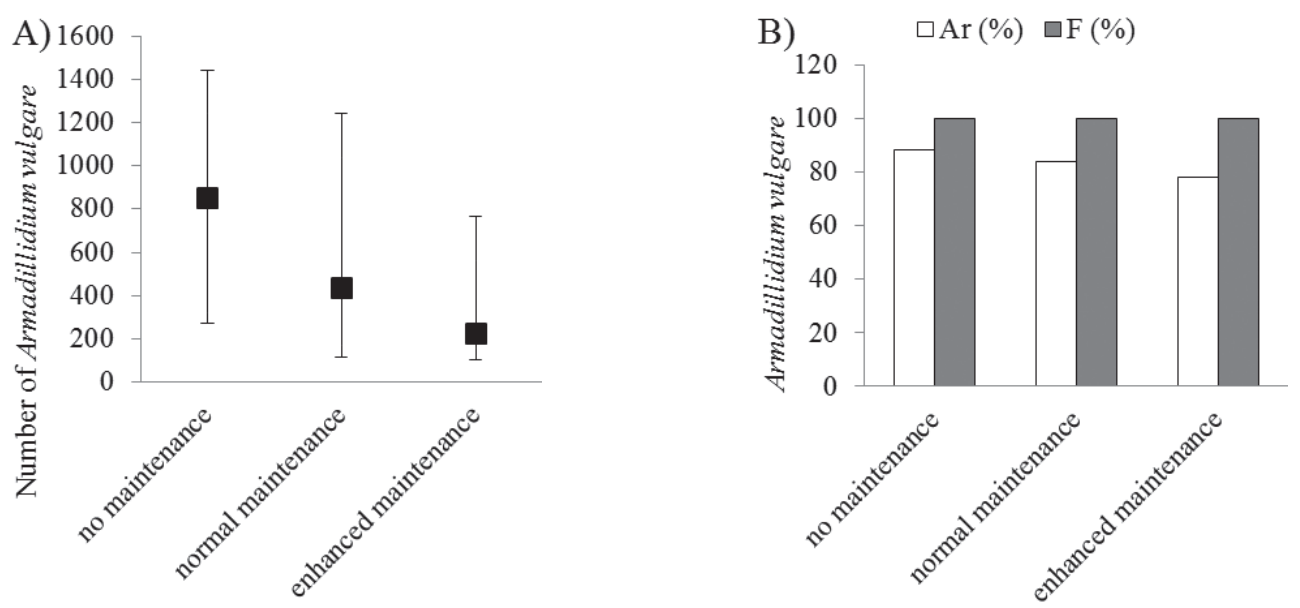

Figure 11. Abundance $(N)$ and relative abundance and frequency (B) of A. vulgare in mainroad verges relative to mowing intensity (average \pm S.E.).

pling sites at $0 \mathrm{~cm}$ leaf-litter depth, and it was significantly lowest in sampling sites with $3 \mathrm{~cm}$ leaf-litter depth compared to sampling sites with $5 \mathrm{~cm}$ leaf-litter depth. The relative abundance of $A$. vulgare was lowest in sampling sites at $2 \mathrm{~cm}$ leaf-litter depth and the frequency of the species was equal in each verges except for the sites at $4 \mathrm{~cm}$ leaf-litter depth (Figure 8).

We observed statistically significant differences in number of $A$. vulgare $(\mathrm{p}=0.010)$ in relation to years when highway have been finished. The abundance of the species 
was significantly highest in verges that were established in 2002 compared to other verges. The relative abundance of $A$. vulgare increased from old verges to young verges and the frequency of the species was equal in each verge types (Figure 9).

\section{Main roads}

Statistically significant differences were no found between number of $A$. vulgare $(\mathrm{p}=0.886)$ in relation to vegetation type of main roads. The highest number of relative abundance of $A$. vulgare were in arid grassland and in wetland, while the lowest was in the forested verges (Figure 10).

Finally, along main roads, significant differences were no found between number of $A$. vulgare $(\mathrm{p}=0.370)$ in relation to mowing intensity. The mowing negatively affected the number of individuals and the relative abundance of $A$. vulgare. The highest number of specimens and relative abundance of the species were recorded in the no maintenance sections, whereas the lowest number was in enhanced maintenance sections (Figure 11).

\section{DISCUSSION}

\section{Highways}

The isopod fauna of roadside verges are not typically the focus of zoological research, and there are few published studies on this taxon. We are the first researchers to examine the isopod fauna along roads in Hungary. The holomediterranean $A$. vulgare, which is a typical indicator of anthropogenic impacts (27), probably originated in the eastern mediterranean region (28). In Hungary, $A$. vulgare was initially discovered by Csiki Endre in 1926 in Budapest, Bodajk and Pápa (29). This widely distributed species can be found in most parts of the world, and is associated with high human activity and has a broad ecological tolerance (28). This life history may explain why this species can colonise disturbed habitats such as roadsides. The high abundance of $A$. vulgare reflects the environmental tolerance and invasive nature of this species. A. vulgare is one of the most common species of isopod in Hungary (25). The abundance of $A$. vulgare was observed to be similar to other habitats in Hungary. Our results compare well to Szlávec (30) in Hortobágy National Park, Farkas $(31,32)$ in Somogy county, in Baranya county (33) and in Tolna county (34) A. vulgare was one of the most frequent and abundant species in the areas examined. Hornung et al. (12, 35) studied isopods in Budapest and other cities and observed that $A$. vulgare was the widest spread and common species.

The high number of traps we deployed along highways made it possible to assess the relationship between isopod diversity and the high abundance of $A$. vulgare. Our results support our hypothesis that $A$. vulgare has a negative effect on the diversity of the isopod communities.
Davis (36) examined isopods in a dune grassland and observed that $A$. vulgare showed a sudden increase in aggregation in 1968 and 1973. Similarly, by examining the annual population dynamics, we found that the increasing abundance of $A$. vulgare was related to the decreasing isopod diversity on highways. Horváth et al. (37), Magura et al. (38) and Bogyó et al. (39) concluded that while the populations of species that are successful adapters increase, the distribution and occurrence of less-adaptive species decreases.

Our results based on seasonality do not support the hypothesis that the highest abundance of $A$. vulgare is in autumn. The high abundance of species in summer on highway verges might be explained by the high reproductive potential (40), excellent adaptation ability and dehydration tolerance (41). In isopods, the main mechanism for water loss is evaporation from the respiratory organs and the body surface (42). Isopods differ expressly in their ability to tolerate dry conditions (43). Arid-tolerant-species have a complex structural respiratory system and thick cuticle (44). Among the examined Hungarian Armadillidium species (A. zenkeri, A. nasatum, A. versicolor, $A$. vulgare), $A$. vulgare has the thickest cuticle and an extremely structured respiratory system (41), and is able to take up $94 \%$ of its normal oxygen requirement in dry air with a dry integument (45). According to many published studies, the long-day photoperiods (46) and the warm temperatures (47) stimulate the reproduction and the growth of the offspring (48) of $A$. vulgare. This species produced larger offspring when the food supply of females is reduced, for example, in summer when food availability and quality is low (49). Moreover, females may not produce offspring until the third year, which will be smaller in size (48).

The larger difference between the fragmented and the adjacent land in vegetation structure is expected to lead to microclimate differences and hence, a greater edge effect (50). To test our hypotheses we compared highway sampling sites based on adjacent areas. Our results clearly demonstrate that sites near arable fields proved to be more advantageous to $A$. vulgare. Human activity stresses soil communities due to heavy fertilizer use, frequent biocide treatment and export of nutrient and organic matter (51). Conversely, many studies show that the margins of arable fields rapidly produce biodiversity benefits for the soil macrofauna $(52,53)$. The high abundance of $A$. vulgare recorded near arable fields reflects the species' ability to adapt to disturbed and open habitats. Wolters \& Ekschmitt (51) showed that although the abundance and diversity of isopods in arable lands is very low, marginal habitats adjacent to arable lands have the highest abundance.

Our data showed that $A$. vulgare abundance was highest at intermediate $(40 \mathrm{~m})$ distances from the road, which supported our hypothesis. Roadside verges have a specific flora and fauna, contained within an ecotone (54). 
Delgado et al. (55) showed that the highest frequency of litter invertebrate species occurred close to a road (10 and $20 \mathrm{~m}$ from the edge).

We expected that the highest number of $A$. vulgare would be observed in sampling sites that had the thickest leaf-litter, but our result does not support this hypothesis. It is known that isopods are responsible for most of the decomposition of organic matter, mostly leaf litter decomposition (56). The leaf-litter and its microorganisms serve as food sources for isopods. Moreover, the surfaces of plant residues have much more active microbial biomass than in the soil (57). However, we found that the $0 \mathrm{~cm}$ thick leaf-litter provided the most suitable habitat for $A$. vulgare. Thick leaf-litter has increased $\mathrm{CO}_{2}$ levels, which has a negative effect on the fertility of isopods (58). Panlasigui (27) showed that $A$. vulgare displays a preference for leaf-litter with a water content of 0.39 compared to litter with a water content 0.53 .

Because the regeneration of natural vegetation going on 30-40 years, we expected the highest abundance on the oldest highway sampling site, but our hypothesis was not supported by this result. Several studies show that many invader plant and animal species'colonies have expanded along roads where the age of roads has an impact on the diversity and abundance of organisms $(7,59,60$, $61,62,63)$. Similarly, we found an increase in the relative abundance of $A$. vulgare that probably reflected the invasive patterns of the species. Along with Hungarian highways, Fetykó (64) observed only a slight increase in the number of scale insects in the old sampling sites, but Lengyel et al. (63) provided evidence for a growing population of spotted wing drosophila at such sites.

\section{Main roads}

The highest abundance of $A$. vulgare was in arid grasslands, which confirmed our original hypothesis. We conclude that $A$. vulgare is a typical and common species of drier areas $(65,45,66)$. Miller \& Cameron (67) showed that survivorship of $A$. vulgare in Texas was highest in grassland areas. Roadside verges of Hungary typically consist of grassy vegetation, habitats that may be facilitating the invasion and spread of $A$. vulgare. The road stretches examined are located in lowland areas that bypass the mountain regions, which may also explain the high biomass of $A$. vulgare on roadside verges. According to our data, abundance of $A$. vulgare was highest in grassy verges of main roads compared to other verge types. According to Farkas \& Vilisics (25), this cosmopolitan species has a ubiquitous distribution in Hungary, except for protected hardwood forests. Our findings concur with Farkas \& Vilisics (25) in addition, the relative abundance of $A$. vulgare was lowest in the forested verges of main roads and highway verges near forests. Few studies have examined isopod communities in Hungarian mountainous areas. In the North-Vértes Mountains, and in Hungarian Nort- hern Mountains, Kontschán $(68,69)$ observed that $A$. vulgare was not common. In Mátra Mountains, Vona-Túri \& Szmatona-Túri (70) found that the species was not dominant. Vilisics \& Hornung (71) examined many regions in Hungary: Great Plains, Little Plains, Western Hungary, Transdanubian Hills, Transdanubian Mountain Range, Northern Mountain Range, Aggtelek National Park and Budapest. According to their studies $A$. vulgare dominated the isopod communities, but the species was not detected in the Northern Mountain Range. Accordingly, the biogeographical context and habitat structure are likely impacting the spread of $A$. vulgare along roads.

Mowing has a positive effect on floral diversity which contributes to a diverse habitat structure and increasing animal and plant species richness $(72,73,74)$. Responses of isopods to mowing are not well known but studies about other soil-dwelling arthropods suggest that grassland management can alter soil humidity, vegetation structure and lighting conditions (75), factors that likely influence isopod communities. Our result concerning the high abundance on non-mowing sections confirms our hypothesis. Although $A$. vulgare adapt well to dry conditions and disturbance, mowing has a negative effect on the species' abundance.

\section{Conclusion}

Our results demonstrate that the terrestrial isopod $A$. vulgare was common and widespread in Hungarian roadside verges. The ability of this species to successfully colonize open vegetation and its tolerance of dry conditions can be attributed mostly to its anatomical features. Besides roads and traffic, biogeographical context, different land use, water supply, surrounding landscapes, habitat structure and vegetation significantly influence the abundance of $A$. vulgare. The increasing abundance of $A$. vulgare in Hungary is related to the decreasing species diversity of other isopods on highways. Consequently, this invasive species is likely to be a strong determinant of invertebrate community composition and as such may influence ecosystem function along roadside verges in Hungary.

\section{ACKNOWLEDGEMENTS}

We thank Ferenc Kádár for help in the sampling animals. We thank Eszter Illyés (deceased) and Csaba Molnár for their assistance with the botanical survey. The project was funded by k83829 OTKA. We thank the National Road Authority and the field experts for botanical and zoological reference sampling and for measuring the biotic and abiotic environmental parameters of each sampling area. The project was funded by CEDRHarmony. We thank Andrew Hamer (University of Melbourne) for proofreading the manuscript. 


\section{REFERENCES}

1. TROMBULAK S C, FRISSELL C 2000 A. Review of ecological effects of roads on terrestrial and aquatic communities. Conserv. Biol. 14: 18-30. https://doi.org/10.1046/j.1523-1739.2000.99084.x

2. HANSEN M J, CLEVENGER A P 2005 The influence of disturbance and habitat on the presence of non-native plant species along transport corridors. Biol. Conserv. 125 (2): 249-259. https://doi.org/10.1016/j.biocon.2005.03.024

3. PAUCHARD A, ALABACK P B 2006 Edge type defines alien plant species invasions along Pinus contorta burned, highway and clearcut forest edges. For. Ecol. Manage.223: 327-335. https://doi.org/10.1016/j.foreco.2005.11.020

4. KNAPP M, SASKA P, KNAPPOVÁ J, VONIČKA P, MORAVEC P, KURKA A, ANDEL P 2013 The habitat-specific effects of highway proximity on ground-dwelling arthropods: implications for biodiversity conservation. Biol. Conserv. 164: 22-29. https://doi.org/10.1016/j.biocon.2013.04.012

5. TIKKA P M, HOGMANDER H, KOSKI P S 2001 Road and railway verges serve as dispersal corridors for grassland plants. Landsc. Ecol. 16 (7): 659-666.

https://doi.org/10.1023/A:1013120529382

6. HAWBAKER T J, RADELOFF V C, CLAYTON M K, HAMMER R B, GONZALES-ABRAHAM C E 2006 Road development, housing growth and landscape fragmentation in northern Wisconsin: 1937-1999. Ecol. Appl. 16: 1222-1237. https://doi.org/10.1890/1051-0761(2006)016[1222:RDHGAL]2.0. $\mathrm{CO} ; 2$

7. BRISSON J, DE BLOIS S, LAVOIE C 2010 Roadside as invasion pathway for common reed (Phragmites australis). Inv. Plant. Sci. Manag. 3 (4): 506-514. https://doi.org/10.1614/IPSM-09-050.1

8. HOLDEREGGER R, DI GIULIO M 2010 The genetic effects of roads: a review of empirical evidence. Basic Appl. Ecol. 11 (6): 522-531. https://doi.org/10.1016/j.baae.2010.06.006

9. VAN DER REE R, JAEGER J A G, VAN DER GRIFT E A, CLEVENGER A P 2011 Effects of roads and traffic on wildlife populations and landscape function: road ecology is moving towards larger scales. Ecol. Soc. 16 (1): 48.

https://doi.org/10.5751/ES-03982-160148

10. MARTINEZ J J I, WOOL D 2006 Sampling bias in roadsides: the case of galling aphids on Pistacia trees. Biodivers. Conserv. 1-13. https://doi.org/10.1007/s10531-004-6685-2

11. ALARUIKKA D M, KOTZE D J, MATVEINEN K, NIEMELÄ J 2002 Carabid and spider assemblages along an urban to rural gradient in Southern Finland. J. Insect Conserv. 6: 195-206. https://doi.org/10.1023/A:1024432830064

12. HORNUNG E, VILISICS F, SZLÁVECZ K 2007 Hazai szárazföldi ászkarák fajok (Isopoda, Oniscidea) tipizálása két nagyváros, Budapest és Baltimore (ÉK Amerika) összehasonlításának példájával (Standardization of Hungarian terrestrial isopods comparing two big cities, Budapest and Baltimore (North America)). Termvéd Közl.13: 47-58

13. WILLIAMSON M H, FITTER A 1996 The characters of successful invaders. Biol. Conserv. 78(1-2): 163-170. https://doi.org/10.1016/0006-3207(96)00025-0

14. THUILLER W, RICHARDSON D M, MIDGLEY G F 2007 Will Climate Change Promote Alien Plant Invasions? In: Nentwig W (ed.) Biological Invasions. (Ecological Studies Vol. 193).Springer-Verlag, Berlin p. 197-211. https://doi.org/10.1007/978-3-540-36920-2_12

15. LOWE S, BROWNE M, BOUDJELAS S, DE POORTER M 2000100 of the World's Worst Invasive Alien Species. A selection from the Global Invasive Species Database. Published by The Invasive Species Specialist Group (ISSG) a specialist group of the
Species Survival Commission (SSC) of the World Conservation Union (IUCN) p. 12.

16. CHARLES H, DUKES J S 2007 Impacts of Invasive Species on Ecosystem Services. In: Nentwig W. editor. Biological invasions (Ecological Studies Vol. 193). Springer-Verlag, Berlin, p. 217-237. https://doi.org/10.1007/978-3-540-36920-2_13

17. CLAVERO M, GARCÍA-BERTHOU E 2005 Invasive species are a leading cause of animal extinctions. Trends Ecol. Evol. 20: 110. https://doi.org/10.1016/j.tree.2005.01.003

18. HASSALL M, HELDEN A, BENTON T 2003 Phenotypic plasticity and interpopulation differences in life history traits of Armadillidium vulgare (Isopoda: Oniscidea). Oecologia 137: 85-89. https://doi.org/10.1007/s00442-003-1325-1

19. HAMMER O, HARPER DAT, RYAN PD 2001 PAST: Paleontological Statistics software package for education and data analysis. Palaeontol. Electron. 4 (1): 9

20. NAGENDRA H 2002 Opposite trends in response for the Shannon and Simpson indices of landscape diversity. Appl. Geogr. 22 (2): 175-186. https://doi.org/10.1016/S0143-6228(02)00002-4

21. HILL T C J, WALSH K A, HARRIS J A, MOFFETT B F 2003 Using ecological diversity measures with bacterial communities. FEMS Microbiol. Ecol. 43 (1): 1-11.

https://doi.org/10.1111/j.1574-6941.2003.tb01040.x

22. MAGURRAN A E 2003 Measuring Biological Diversity. Blackwell Publishing Oxford. 264 p.

23. HOPKIN S P 1991 A Key to the Woodlice of Britain and Ireland. AIDGAP, Field Studies7, England p. 599-650

24. SCHMIDT C 1997 Revision of the European species of thegenus Trachelipus Budde-Lund, 1908 (Crustacea: Isopoda: Oniscidea). Zool. J. Linn. Soc. 121: 129-244.

https://doi.org/10.1111/j.1096-3642.1997.tb00337.x

25. FARKAS S, VILISICS F 2013 Magyarország szárazföldi ászkarák faunájának határozója (Isopoda: Oniscidea) (A Key to the Terrestrial Isopods of Hungary). Nat. Somogy. 23: 89-124

26. SCHMALFUSS H 2003 World catalog of terrestrial isopods (Isopoda: Oniscidea). Stuttgart: Beitr. Naturk. Ser. A. Nr.; 654: 341 p.

27. PANLASIGUI S 2011 Choosy Crustaceans: Habitat Preference of the Terrestrial Isopod, Armadillidium vulgare (Isopoda: Oniscidea). Terrestrial Isopod Habitat Preferencen. pag. Nature. berkeley. edu.

28. SCHMALFUSS H 2000 Distributional patterns in the Greek species of the terrestrial isopod genus Armadillidium Brandt, 1833. Belg. J. Zool. 130 (Supplement): 77-82

29. FORRÓ L, FARKAS S 1998 Checklist, preliminary distribution maps, and bibliography of woodlice in Hungary. Misc. Zool. Hung. 12: 21-44

30. SZLÁVECZ K 1991 The terrestrial isopod fauna of the Hortobágy National Park. Misc. Zool. Hung. 6: 61-66

31. FARKAS S 1998 A Rinya-ártér Isopoda faunája I. Bakháza (The Isopoda fauna of the Rinya region. Bakháza (Hungary). Nat. Somogy. XIII. 257-262

32. FARKAS S 2004 Data to the knowledge of the terrestrial Isopod (Isopoda: Oniscidea) fauna of Somogy county (Hungary: South Transdanubia). Nat. Somogy. 16: 313-323

33. FARKAS S 2005 Data to the knowledge of the terrestrial Isopod (Isopoda: Oniscidea) fauna of Baranya county (Hungary: South Transdanubia). Acta Kaposvariensis 9 (1): 67-86

34. FARKAS S 2006 Tolna megye szárazföldi ászkarákfaunájának (Isopoda: Oniscidea) alapvetése. (Data to the knowledge of the terrestrial Isopod (Isopoda: Oniscidea) fauna of Tolna county (Hungary: South Transdanubia)). Állattani Közl. 91 (1): 29-42

35. HORNUNG E, VILISICS F, SÓLYMOS P 2009 Ászkarák együttesek (Crustacea, Isopoda, Oniscidea) felhasználhatósága élőhelyek minősítésében (The use of woodlice assemblages (Crus- 
tacea, Isopoda, Oniscidea) in the assessment of habitat naturalness). Termvéd Közl. 15: 381-395

36. DAVIS R C 1984 Effects of Weather and Habitat Structure on the Population Dynamics of Isopods in a Dune Grassland. Oikos 42: 387-395. https://doi.org/10.2307/3544409

37. HORVÁTH R, MAGURA T, TÓTHMÉRÉSZ B 2012 Ignoring ecological demands masks the real effect of urbanization: a case study of ground-dwelling spiders along a rural-urban gradient in a lowland forest in Hungary. Ecol. Res. 27: 1069-1077. https://doi.org/10.1007/s11284-012-0988-7

38. MAGURA T, NAGY D, TÓTHMÉRÉSZ, B 2013 Rove beetles respond heterogeneously to urbanization. J. Insect Conserv. 17: 715-724. https://doi.org/10.1007/s10841-013-9555-y

39. BOGYÓ D, MAGURA T, SIMON E, TÓTHMÉRÉSZ B 2015 Millipede (Diplopoda) assemblages alter drastically by urbanisation. Landsc. Urban Plan. 133: 118-126. https://doi.org/10.1016/j.landurbplan.2014.09.014

40. QUADROS A F, CAUBET Y, ARAUJO P B 2009 Life history comparison of two terrestrial isopods in relation to habitat specialization. Acta Oecol. 35: 243-249.

https://doi.org/10.1016/j.actao.2008.10.007

41. CSONKA D, HALASY K, MRAK P, ŠTRUS J, HORNUNG E 2012 Armadillidium-fajok (Isopoda: Oniscidea) élőhelyi adaptációjának morfológiai háttere (The morphological background of the habitat adaptation of Armadillidium (Isopoda: Oniscidea) species). Termvéd. Közl. 18: 115-126

42. KUENEN D J 1959 Excretion and water balance in some land isopods. Entomol. Exp. Appl. 2: 287- 294.

https://doi.org/10.1111/j.1570-7458.1959.tb00442.x

43. SMIGEL J T, A G Gibbs 2008 Conglobation in the pill bug, Armadillidium vulgare, as water conservation mechanism. J. Insect. Sci. 8 (1): 44. https://doi.org/10.1673/031.008.4401

44. PAOLI P, FERRARA F, TAITI S 2002 Morphology and evolution of the respiratory apparatus in the family Eubelidae (Crustacea, Isopoda, Oniscidea). J. Morphol. 253: 272-289. https://doi.org/10.1002/jmor.10008

45. CLOUDSLEY-THOMPSON J L 1977 The Water and Temperature Relations of Woodlice. Meadowfield Press, England, p. 84

46. MOCQUARD J P, JUCHAULT P, SOUTY-GROSSET C 1989 The role of environmental factors (temperature and photoperiod) in the reproduction of the terrestrial isopod Armadillidium vulgare (Latreille, 1804). Monitore Zool. Ital. 4: 455-475

47. MADHAVAN K, SHRIBBS J M 1981 Role of photoperiod and low temperature in the control of ovigerous molt in the terrestrial isopod Armadillidium vulgare (Latreille, 1804). Crustaceana 41: 263 - 270. https://doi.org/10.1163/156854081X00840

48. HELDEN A J, HASSALL M 1998 Phenotypic plasticity in growth and development rates of Armadillidium vulgare (Isopoda: Oniscidea). Israel J. Zoo.44: 379-394

49. BRODY M S, LAWLOR L R 1984 Adaptive variation in offspring size in the terrestrial isopod, Armadillidium vulgare. Oecologia 61 (1): 55-59. https://doi.org/10.1007/BF00379089

50. RIES L, FLETCHER R J, BATTIN J, SISK T D 2004 Ecological responses to habitat edges: mechanisms, models, and variability explained. Annu. Rev. Ecol. Evol. Syst. 35:491-522. https://doi.org/10.1146/annurev.ecolsys.35.112202.130148

51. WOLTERS V, EKSCHMITT K 1997 Gastropods, Isopods, Diplopods, and Chilopods: Neglected Groups of Decomposer Food Web. In: Benckiser G (ed.) Fauna in Soil Ecosystems: recycling processes, nutrient fluxes, and agriculture production. Marcel Dekker, Inc. New York, p. 279-281

52. MEEK B, LOXTON D, SPARKS T, PYWELL R, PICKETT H, NOWAKOWSKI M 2002 The effect of arable field margin composition on invertebrate biodiversity. Biol. Conserv. 106, 259-271. https://doi.org/10.1016/S0006-3207(01)00252-X
53. SMITH J, POTTS S, EGGLETON P 2008 The value of sown grass margins for enhancing soil macrofaunal biodiversity in arable systems. Agric. Ecosyst. Environ.127:119-125.

https://doi.org/10.1016/j.agee.2008.03.008

54. RISSER P G 1995 The status of the science examining ecotones. BioScience 45:318-325. https://doi.org/10.2307/1312492

55. DELGADO J D, ARROYO N L, ARÉVALO J R, FERNÁNDEZ-PALACIOS J M 2013 The responses of leaf litter invertebrates to environmental gradients along road edges in subtropical island forests. Pedobiology 56:137-146. https://doi.org/10.1016/j.pedobi.2013.01.003

56. ABD EL-WAKEIL K F 2015 Effects of terrestrial isopods (Crustacea: Oniscidea) on leaf litter decomposition processes. J. Basic Appl. Zool. 69:10-16. https://doi.org/10.1016/j.jobaz.2015.05.002

57. WEST A W, SPARLING G P 1986 Modifications to the substrate-induced respiration method to permit measurement of microbial biomass in soils of different water contents. J. Microbiol. Methods. 5:177-189. https://doi.org/10.1016/0167-7012(86)90012-6

58. DAVID J, GILLON D 2009 Combined effects of elevated temperatures and reduced leaf litter quality on the life-history parameters of a saprophagous macroarthropod. Glob. Change Biol. 15: 156165. https://doi.org/10.1111/j.1365-2486.2008.01711.x

59. GELBARD J L, BELNAP J 2003 Roads as conduits for exotic plant invasions in a semiarid landscape. Conserv. Biol. 17: 420432. https://doi.org/10.1046/j.1523-1739.2003.01408.x

60. CHRISTEN D, MATLACK G 2006 The role of roadsides in plant invasions: a demographic approach. Conserv. Biol. 20: 385-391. https://doi.org/10.1111/j.1523-1739.2006.00315.x

61. JODOIN Y, LAVOIE C, VILLENEUVE P, THERIAULT M, BEAULIEU J, BELZILE F 2008 Highways as corridors and habitats for the invasive common reed Phragmites australis in Quebec, Canada. J. Appl. Ecol. 45:459-466. https://doi.org/10.1111/j.1365-2664.2007.01362.x

62. MEUNIER G, LAVOIE C 2012 Roads as Corridors for Invasive Plant Species: New Evidence from Smooth Bedstraw (Galium mollugo). Inv. Plant. Sci. Manag. 5 (1): 92-100. https://doi.org/10.1614/IPSM-D-11-00049.1

63. LENGYEL G D, OROSZ S, KISS B, LUPTÁK R, KÁRPÁTI ZS 2015 New records and present status of the invasive spotted wing drosophila, Drosophila suzukii (Matsumura, 1931) (Diptera) Drosophila suzukii (Matsumura, 1931) (Diptera) in Hungary. Acta Zool. Hung. 61 (1): 73-80. https://doi.org/10.17109/AZH.61.1.73.2015

64. FETYKÓ K G 2014 Scale insect communities (Hemiptera: Coccoidea) of Hungarian highways: biocoenology and ecology. $\mathrm{PhD}$ thesis Gödöllo”

65. PARIS O H 1963 The ecology of Armadillidium vulgare (Isopoda: Oniscoidea) in California grassland: food, enemies, and weather. Ecol. Monogr. 33 (1): 1-22. https://doi.org/10.2307/1948475

66. WRIGHT J C, TING K 2006 Respiratory physiology of the Oniscidea: Aerobic capacity and the significance of pleopodal lungs. Comp. Biochem. Physiol. 145: 235- 244. https://doi.org/10.1016/j.cbpa.2006.06.020

67. MILLER R H, CAMERON G N 1983 Intraspecific variation of life history parameters in the terrestrial isopod, Armadillidium vulgare. Oecologia 57: 216-226.

https://doi.org/10.1007/BF00379583

68. KONTSCHÁN J 2001 Adatok Majk (Észak-vértes) magasabbrendủ rák (Crustacea: Amphipoda et Isopoda et Decapoda) faunájához (Data of crustacean fauna (Crustacea: Amphipoda et Isopoda et Decapoda) of Majk (North-Vértes Mts.). Fol. His. Nat. Mus. Matraensis 25: 65-68

69. KONTSCHÁN J 2004 Néhány adat az Északi-középhegység ászkarák faunájához (Crustacea: Isopoda: Oniscidea) (Some data to 
the woodlice fauna of the Hungarian Northern Mountains). Fol. His. Nat. Mus. Matraensis 28: 91-93

70. VONA-TÚRI D, SZMATONA-TÚRI T 2012 Adatok a Mátrahegység ászkarák (Crustacea: Isopoda: Oniscidea) faunájához, különös tekintettel az út menti élőhelyekre (New data to the terrestrial isopoda (Crustacea, Isopoda, Oniscidea) fauna of Mátra-mountains, especially the wayside regions). Termvéd. Közl. 18: $537-548$

71. VILISICS F, HORNUNG E 2010 Újabb adatok Magyarország szárazföldi ászkarákfaunájához (Crustacea, Isopoda, Oniscidea) (New data to the terrestrial isopod (Crustacea, Isopoda, Oniscidea) fauna of Hungary). Állattani Közl. 95 (1): 87-120

72. BUTTLER A 1992 Permanent plot research in wet meadows and cutting experiment. Vegetatio 103 (2): 113-124
73. TEWS J, BROSE U, GRIMM V 2004 Animal species diversity driven by habitat heterogeneity/diversity: the importance of keystone structures. J. Biogeogr. 31 (1): 79-92.

https://doi.org/10.1046/j.0305-0270.2003.00994.x

74. MALUMBRES-OLARTE A, VINK CJ, ROSS J G, RUICKSHANK R H, PATERSON A. M 2013 The role of habitat complexity on spider communities in native alpine grasslands of New Zealand. Insect Conserv. Divers. 6 (2): 124-134. https://doi.org/10.1111/j.1752-4598.2012.00195.x

75. SZMATONA-TÚRI T, VONA-TÚRI D, MAGOS G, URBÁN L 2017 The effect of grassland management on diversity and composition of ground-dwelling spider assemblages in the Mátra Landscape Protection Area of Hungary. Biologia Section Zoology 72(6): 642-651. https://doi.org/10.1515/biolog-2017-0075 